\title{
Non Performing Finance, Third Party Funds, Financing Risk and Inflation to Profit Loss Sharing (Study Empiris on Sharia Commercial Bank in Indonesia BEI Period 2012 - 2016)
}

\author{
Marsyaf \\ Faculty Economics and Business, Universitas Mercu Buana
}

\begin{abstract}
This research aims to know the Non Performing Finance, Third Party Funds, Financing Risk and Inflation on Profit Loss Sharing (Profit). The population in this research are on Sharia Banking listed on Indonesia Stock Exchange in the period 2012-2016. The samples in this research are determined by purposive sampling of 13 companies, where only 9 companies that meet the criteria for the research sample. The data used in this research is secondary data and analysis of data using multiple linear regression analysis using SPSS 20.The result of this research shows that simultaneously, the variable of the Non Performing Finance, Third Party Funds, Financing Risk and Inflation influence Profit Loss Sharing (Profit). It has been proven from the result of F simultant test. The result of partial test ( $t$ test) shows significant point of two independent variables that supports the hipothesys. Therefore, the test result of this research stated that Non Performing Finance have negative and significant effect on Profit Loss Sharing (Profit) and Third Party Funds have positive and significant effect on Profit Loss Sharing (Profit), while the variable of Financing Risk and Inflation do not have significant effect on Profit Loss Sharing (Profit).
\end{abstract}

Keywords: Non Performing Finance, Third Party Funds, Financing Risk, Inflation and Profit.

DOI: $10.7176 /$ RJFA/10-8-13

Publication date: April $30^{\text {th }} 2019$

\section{Introduction}

Indonesia is one of the world's largest Muslim populations, providing a greater opportunity for the development of sharia banking sector. In order to capture the opportunity, Bank Indonesia develops sharia banking sector which is expected to support the sustainable economic development and social welfare as well as the Indonesian economy. The existence of Sharia Banking in Indonesia itself has been formally started since the enactment of Law Number 7 of 1992 concerning Banking as amended by Law Number 10 of 1998 . The Act states that Commercial Bank conducts business activities in a conventional and/or sharia-based principle (Bank Syariah) which in its activities provides services in the payment traffic. The law provides bank freedom in determining the types of benefits to be provided to the customers, either in the form of interest or profit sharing, including the flexibility of determining the interest rate to 0 (zero) which is new in the framework of the banking system mechanism in general. With the enactment of Law Number 21 of 2008 regarding Sharia Banking which was published on July 16, 2008, the development of the national Sharia banking industry has an adequate legal basis and will encourage its growth more rapidly. The development of sharia banking in Indonesia is quite rapid, even exceeds conventional banks. Nevertheless, the development of sharia banking in Indonesia should continue to be conducted in the corridors of prudence and compliance with sharia principles. In terms of infrastructure for the fulfillment of sharia principles, the Indonesian Ulama Council (MajelisUlama Indonesia/MUI) has established the National Sharia Council (DewanSyariahNasional/DSN) as the only party or institution that can issue fatwa related to sharia financial instruments in Indonesia and also establish Sharia Supervisory Council (Dewan Pengawas Syariah /DPS) in banking in order to convince. As an intermediary institution that functions to collect and channel the funds back from the community, banks are faced with various risks.

In running its business as a financial institution as well as a business entity that still wants profit, profit is still an indicator of the success of a bank in running its business. The profit of Sharia Banking in its development has increased up and down. This study aims to analyze to which extent the policy of financing type and pricing policies of a bank can contribute in affecting the increase of bank profits. Researchers more specifically identify factors affecting PLS in sharia banking, because sharia banking has special characteristics in the model of financing. That is the reason of the title election of "Non-Performing Finance, Third Party Funds, Financing Risk and Inflation on the Profit Loss Sharing (Profit) on Sharia Commercial Bank in Indonesia Period 2012 - 2016 "

\section{Literature Review, Framework, Hypothesis}

\subsection{Literature Review}

\subsubsection{Agency Theory}

The concept of agency theory by Anthony and Govindarajan (1995) in Nur (2014) is a contractual relationship between principal and agent, where the principal is the party who employs the agent to perform the task for the 
principal's interest, while the agent is the party that carries the principal interests. Jensen and Meckling (1976) state that "agency relationship as a contract under which one or more person (the principals) engage another person (the agent) to perform some service on their behalf which involves delegating some decision making authority to the agent". This becomes the basis for the need of bank management to report and disclose the bank performance to the owner of the funds (customers) as a form of accountability of bank management to the owner of the funds (customers).

\subsubsection{Profit Loss Sharing}

According to Tarsidin (2010), Profit Sharing is a form of alternative financing scheme which has very different characteristics than interest. As the name implies, this scheme is a division of business proceeds financed by credit/ financing. The profit-sharing scheme can be applied either to direct financing or to financing through sharia banks (in the form of mudharabah and musyarakah financing). In a production sharing contract, it is necessary to design optimal profit sharing schemes which can efficiently encourage the entrepreneurs (borrowers) to do their best and can suppress the occurrence of falsification. The forms of sharing schemes according to Muhammad (2001) are as follows:

Profit sharing (also called as profit-and-loss sharing),

Gross profit sharing,

Revenue sharing

\subsubsection{Non Performing Financing}

According to Tri JokoPurwanto (2011), Non-Performing Financing is the rate of return of financing given by depositors to the bank. In other words, NPF is the bad financing rate in the bank. NPF is known by calculating the Non-Current Financing Against the Total Financing. If the lower the NPF, then the bank will be more profitable, on the contrary, the higher the NPF level, the bank will suffer losses due to the return of the credit is bad. Nonperforming loan consisting of credit which is classified as Substandard is Doubtful and Bad.

\subsubsection{The Third Party Fund}

According to Muhammad Nizar (2012: 5), the collection of public funds in sharia banking using the same instrument as the funding of conventional banks, namely the current account, savings and time deposits. These three types of instruments are commonly referred to as the Third Party Funds (Dana PihakKetiga/DPK). Although they use the same instrument, the mechanism of work of each instrument in the Sharia bank union is different from the conventional bank collection instrument. The fundamental difference in the working mechanism of Sharia fundraising instrument lies in the absence of interest that is commonly used in conventional banks to provide benefits to the customers.

\subsubsection{Financing and profit sharing principles}

According to Adiwarman A. Karim, 2009, the Profit Sharing Principle is an essential part in sharia banking operational activities, the principle of profit sharing is the implementation of the principle of justice, equality in sharia economic transactions, even the Sharia bank itself are very closely related to the term bank for results. With adequate constitutional support in the form of existing legislation, Bank Indonesia Regulations (PBI) and Fatwa issued by the National Sharia Council (DSN), Sharia banking which in its operational activities should always be based on the principles of sharia, have a great opportunity to uphold the national economy based on the principle of economic democracy with the principle of togetherness, efficiency fairness, sustainability, environmental insight, independence, and by maintaining the balance of progress and national economic unity. In practice, Sharia Banks apply the principle to financing products based Natural Uncertainty Contracts (NUC), which is a business contract that does not provide income certainty (returning), both in terms of amount and time, such as financing mudharabah and musharakah.

\subsubsection{Inflation}

From the existingdefinition of inflation, it can be drawn three points (Gunawan, 1991), those are:

a. There is a tendency for the prices to increase, which is maybe a possibility that the prices change at certain times compared to the previous ones, but still, show an increasing tendency.

b. The price increase continuously, it does not happen at any one time. According to Rahardja and Manurung (2004), an economy is considered to have experienced inflation if the following three characteristics are met, those are:

a. price increases,

b. price increases are general, and

\section{Methodology}

\subsection{Time and Place of Research}

The research focuses on the financial statements of sharia banks listed on the Indonesia Stock Exchange, both sources of funds and outputs, for the period 2012-2015. The collection of research data was conducted on July 1, 2017 - October 14, 2017 


\subsection{Research Design}

The design used in this study is causal. This study was conducted to determine the influence of one or more independent variables with dependent variable, ie Non-perfoming financing, Mudharabah and Musyarakah financing ratio, Inflation and Third Party Fund effect on Profit Sharing of Sharia Commercial Bank in Indonesia Period $2012-2016$

\subsection{Definitions and Operational Variables}

\section{a. Profit Loss Sharing (LABA)}

The dependent variable or dependent variable is a variable that is explained or influenced by an independent variable. Dependent variable used in this research is Financing Risk to Profit Loss Sharing Financing (PLS), which referred to PLS in this research is net profit before tax and get from total of all revenue and minus total cost, according to research of Yudho Prabowo (2009) this variable is formulated as follows:

$$
\mathrm{IBT}=\mathrm{TR}-\mathrm{TC}
$$

$$
\begin{array}{ll}
\text { EBT } & \text { : Income Before Tax } \\
\text { TR } & \text { : Total Revenue } \\
\text { TC } & \text { : Total Cost }
\end{array}
$$

\section{b. Non performing financing}

As an indicator that shows the loss due to credit risk is reflected in the amount of non performing loan (NPL), in terminology of Islamic banks called non-perfoming financing (NPF). Non Performing Financing (NPF) is the ratio between financing problem with total financing disbursed by banks sharia. Based on the criteria set by Bank Indonesia, the categories included in the NPF are current financing, doubtful and loss. According to research Wuri Arianti N.P (2012) is formulated as follows:

\section{Pembiayaan Diragukan + Pembiayaan Macet + Pembiayaan KurangLancar} Total Pembiayaan

\section{c. Third Party Funds}

Funds from the public to improve the operating profit sayriah bank, and therefore the Management will maintain public confidence in raising funds either in the form of deposits, demand deposits and savings. Third party funds in sharia banking are obtained from the Statement of Financial Position:

\section{Dana Pihak Ketiga $=$ Dana Syirkah Temporer + Tabungan dan \\ Giro Wadiah (Bukan Bank)}

a. Kasıo IInancing

Funding Ratio to Revenue Sharing of total financing, types of financing for these results consist of profit and Musharaka financing where financing for the results considered to have a risk that research tinggi.Menurut Kinasih Septrivia Revelation (2013) variance calculation is formulated as follows:

\section{Pendapatan Pembiayaan PLS}

\section{Pendapatan Total Pembiayaan}

\section{e. inflation}

Increased inflation in a country also causes the price of goods and services to increase. Inflation value in a certain year compared with the previous period, in this study for the Inflation figures taken from the website of Bank Indonesia www.bi.go.id.To determine the rate of inflation or the rate of inflation used the Consumer Price Index (CPI) as the basis for the calculation of the formula:

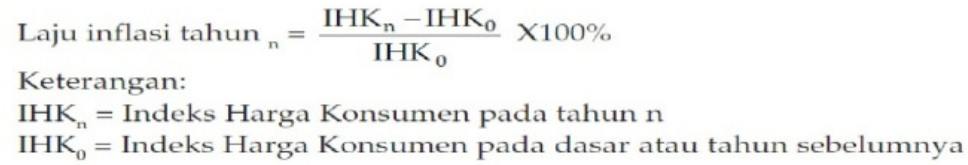

\section{4. population and sample research}

Population in this research is all national sharia bank (BUS) of national scale in Indonesia. Based on data from Indonesian Islamic Banking Statistics Annual per January 2017, in 2016 there were 13 BUS scattered throughout Indonesia. According to Ghozali (2013) the sample is part of the number and characteristics possessed by the population. The sample in this study was determined using 
purposive sampling method to obtain a sample that representatives in accordance with the criteria specified. The criteria used is based on research Pramon (2013) are as follows:

a. An Islamic Banks in Indonesia

b. Islamic Banks recorded at Bank Indonesia in the period 2012-2016

c. Islamic Banks which presents the annual financial statements in the period 2012 to 2016 annual that can be accessed via the internet

d. Islamic banks that publish the complete annual financial statements during the study period, with completion criteria based on SFAS 101 on the Islamic financial statement presentation

e. Profit on Islamic banks in Indonesia during the period 2012-2016.

f. Profit on Islamic banks in Indonesia during the period 2012-2016.

\section{Result and Discussion}

\subsection{General Description}

Descriptive statistics provide a description of a data viewed from the minimum, maximum, mean and standard deviation. Minimum value is the lowest value for each variable, while the maximum value is the highest value for each variable in the study. The mean value is the average value of each variable studied and the standard deviation is the distribution of data used in the study which reflects the data distribution is homogeneous or heterogeneous. The following is a general descriptive of statistical analysis result of the data used. The variable data is transformed due to heteroscedasticity on the Third Party Fund variable to normalize, then two variables use the ratio of rupiah transformed to $\ln$

\subsection{Descriptive Statistic Analysis}

\section{Tabel 4.1}

Descriptive Statistics

Descriptive Statistics
\begin{tabular}{|l|l|l|l|l|l|}
\hline & N & Minimum & Maximum & Mean & $\begin{array}{l}\text { Std. } \\
\text { Deviation }\end{array}$ \\
\hline NPF & 45 & 0.001 & 0.07 & 0.0332 & 0.01845 \\
DPK & 45 & 13.85 & 17.92 & 15.8838 & 1.13136 \\
RF & 45 & 0.0037 & 0.24 & 0.1043 & 0.0454 \\
INF & 45 & 0.0302 & 0.0838 & 0.0548 & 0.02422 \\
LABA & 45 & 9.3 & 13.91 & 11.3644 & 1.28021 \\
Valid N & & & & & \\
(listwise) & 45 & & & & \\
\hline
\end{tabular}

PROFIT is a dependent variable proxied with the Income Before Tax (IBT). This variable has a minimum value of 9.30 which is the Income BeforeTaxBank of Central Asia Sharia (BCA Syariah) in 2012. This minimum value occurs because the company cannot maximize the net profit gain in 2012 as return on equity provided by the owner. The maximum value of this variable is 13.91 which is the Income Before Tax of Sharia Mandiri Bank (BSM) in 2012. This maximum value is obtained due to a decrease in the amount of equity in 2012 but the net profit earned is increased so that return on equity can be maximized. The mean value of Income Before Tax of 45 data is 11.3644 with a standard deviation of 1.28021 . The value of the standard deviation that is smaller than the mean value indicates that the data distribution is quite homogeneous.

NPF is an independent variable of problem financing proxied with Non Performing Financing (NPF). This variable has a minimum value of 0.001 which is the Non Performing Financing Bank of Central Asia Sharia (BCA Syariah) in 2012 and 2013. This minimum value occurs because the company can maximize the collection of accounts receivable in 2012 as a refund of the financed funds disbursed. The maximum value of this variable is 0.07 which is the Non Performing Financing (NPF) of Muamalat Bank in 2015. This maximum value is obtained because there is a decrease in the amount of receivable billing in 2014 so that the amount of bad debts rise and affect the profit of a company. The mean value of Performing Financing (NPF) of 45 data is 0.0332 with a standard deviation of 0.01845 . The value of the standard deviation that is smaller than the mean value indicates that the data distribution is quite homogeneous.

DPK is an independent variable of public Fund proxied with the Third Party Fund. This variable has a minimum value of 13.85 which is a Third Party Fund of Central Bank Sharia (BCA Syariah) in 2012. This minimum value occurs due to the lack of public trust in the banking company to save their money because the declining value of DPK will affect the profit decrease. The maximum value of this variable is 17.92 which is a Third Syariah Bank Sharia Mandiri Fund (BSM) in 2016. This maximum value is obtained due to an increase in the amount of deposits from the Public Fund in 2016 so that the number of Third Party Funds affect the increase in Profit. The average value of Third Party Funds of 45 data is 15.8838 with a standard deviation of 1.13136 . The 
value of the standard deviation that is smaller than the mean value indicates that the data distribution is quite homogeneous.

$\mathrm{RF}$ is an independent variable of revenue sharing for the financing proxied with the Financing Ratio. This variable has a minimum value of 0.0037 which is the ratio of Panin Sharia Financing Bank in 2016. This minimum value occurs due to the lack of the use of mudharabah financing schemes and the uncertainty of the financing results of the profit sharing as the return of fund disbursed. The maximum value of this variable is 0.24 which is the Financing Bank ratio of Central Asia Sharia in 2015. This maximum value is obtained because of the increased use of profit sharing financing and the earnings results will increase the company profit. The mean value of the Financing Ratio of 45 data is 0.1043 with a standard deviation of 0.04540 . The value of the standard deviation that is smaller than the mean value indicates that the data distribution is quite homogeneous.

INF is an independent variable Inflation. This variable has a minimum value of 0.0302 which is the Inflation in 2016. This minimum value occurs due to the increased purchasing power of the community and the decrease of interest rates resulting in reduced public interest to disburse their money. The maximum value of this variable is 0.0838 which is the Inflation in 2013. This maximum value is obtained due to the decreasing of community's purchasing power and the increase of interest rate so that the interest of the society to disburse the circulating money to the Bank in order to increase the profit. The mean value of the Financing Ratio of 45 data is 0.0548 with the standard deviation of 0.02422 . The value of the standard deviation that is smaller than the mean value indicates that the data distribution is quite homogeneous.

\section{Hypothesis Testing}

\section{Determination Coefficient Test $\left(\mathbf{R}_{2}\right)$}

The determination coefficient test is used to measure how far the ability of the model in explaining the variation of independent variables to the dependent variable. The value of the determination coefficient shown by the value of Adjusted R2 from the regression model is used to determine the variable size of the dependent variable which can be explained by the independent variable. Here is the test result of the determination coefficient (R2).

Table 4.6

Coefficient Determination Test Results Model Summaryb

\begin{tabular}{|r|r|r|r|r|}
\hline Model & \multicolumn{1}{|c|}{ R } & R Square & $\begin{array}{r}\text { Adjusted } \\
\text { R Square }\end{array}$ & $\begin{array}{c}\text { Std. Error } \\
\text { of the } \\
\text { Estimate }\end{array}$ \\
\hline 1 & $.788^{\mathrm{a}}$ & 0.622 & 0.584 & 0.82601 \\
\hline
\end{tabular}

a. Predictors: (Constant), INF, NPF, RF, DPK

b. Dependent Variable: LABA

Adjusted R Square (R2) value is 0.584 , this means that $58.4 \%$ of Income Before Tax (PROFIT) variation can be explained by four independent variables which are Non Performing Financing, Third Party Fund (DPK), Revenue Sharing on Financing (Ratio Financing), and Inflation (INF). Meanwhile, the remaining 41.6\% is explained by other variables that are not used in this study.

\section{Simultaneous Significance Test (F Statistic Test)}

The simultaneous significance test (F test) basically indicates whether all the independent variables included in the model have an effect simultaneously on the dependent variable. The following table shows the results of $\mathrm{F}$ Test:

Table 4.7

Simultaneous Significance Test Results

ANOVA ${ }^{a}$

\begin{tabular}{|c|c|c|c|c|c|}
\hline Model & $\begin{array}{l}\text { Sum of } \\
\text { Squares }\end{array}$ & df & $\begin{array}{l}\text { Mean } \\
\text { Square }\end{array}$ & $\mathrm{F}$ & Sig. \\
\hline $\begin{array}{ll} & \text { Regressio } \\
\text { n } \\
\text { Residual } \\
1 \text { Total }\end{array}$ & $\begin{array}{l}44.821 \\
27.292 \\
72.113\end{array}$ & $\begin{array}{r}4 \\
40 \\
44\end{array}$ & $\begin{array}{r}11.205 \\
0.682\end{array}$ & 16.423 &, $000^{\mathrm{b}}$ \\
\hline
\end{tabular}

a. Dependent Variable: LABA

b. Predictors: (Constant), INF, NPF, RF, DPK

Based on table 4.7 above, the $\mathrm{F}$ test value of 16.423 and significant at 0.000 . This significant value is much smaller than the alpha value of 0.05 , then the regression model can be used to predict PROFIT or it can be said that NPF, DPK, RF, and INF together affect the PROFIT.

3. Individual Parameter Test (t-test)

The significance test of individual parameters $(\mathrm{t})$ aims to determine whether the independent variable influences 
the dependent variable partially. The following shows the results of the t-test in this study:

Table 4.8

Test $-\mathbf{t}$ Result

\begin{tabular}{|l|c|c|c|c|c|}
\hline \multirow{2}{*}{ Model } & \multicolumn{2}{|c|}{$\begin{array}{c}\text { Unstandardized } \\
\text { Coefficients }\end{array}$} & $\begin{array}{c}\text { Standardi } \\
\text { zed } \\
\text { Coefficien } \\
\text { ts }\end{array}$ & Sig. & \\
& \multicolumn{2}{|c|}{ B } & Std. Error & Beta & \\
\cline { 2 - 6 } & & & & & \\
\hline 1 & -3.832 & 2.194 & & -1.747 & 0.088 \\
(Constant) & -22.729 & 8.427 & -0.328 & -2.697 & 0.01 \\
NPF & 1.031 & 0.139 & 0.911 & 7.395 & 0 \\
DPK & -1.383 & 2.859 & -0.049 & -0.484 & 0.631 \\
RF & -5.115 & 5.166 & -0.097 & -0.99 & 0.328 \\
INF & & & & & \\
\hline
\end{tabular}

a. Predictors: (Constant), INF, NPF, RF, DPK

b. Dependent Variable: LABA

\section{a. PROFIT}

The regression analysis in this study use the data amount $(n)=45$ and the independent variable $(k)=4$, therefore obtained the degree of freedom (df) $=\mathrm{n}-\mathrm{k}=45-4=41$, so obtained the t value table of 2.01954. From the four independent variables included in this regression model, Non-Performing Financing and third-party funds (DPK) have a significant effect on Income Before Tax because the $t$ value of the two variables is greater than the value of t table, and its significance value is less than 0.05. Meanwhile, the independent variable of Profit Sharing on Financing (Ratio Financing) and Inflation (INF) does not affect the Profit because the value of t is less than $t$ table, and its significance value is more than 0.05 .

\section{Multiple Linear Regression Test}

To test whether there is an effect of liquidity, working capital rotation, capital structure, receivable rotation and operating efficiency on profitability or not, multiple linear regression is used. Based on Table 4.8, the RF and INF variables do not have an effect on the PROFIT because the probability significance value for RF is 0.631 and INF is 0.328 which are far above 0.05 . Meanwhile, the NPF and DPK variables have a significant value of 0.010 and 0.000 respectively, which is much smaller than 0.05 . Then, it can be concluded that the PROFIT variable is affected by NPF and DPK by the following regression equation:

Becomes:

$$
\mathrm{Y}=-3,832-22,729 \mathrm{NPF}+1,031 \mathrm{DPK}-1,383 \mathrm{RF}-5,115 \mathrm{INF}
$$

The constant of -3.832 states that if the independent variable is considered constant, then the mean profit of a banking company is -3.832 . The NPF variable regression coefficient of -22.729 (negative coefficient) states that if each Non-Performing Financing experienced an increase of 1 percent, it will reduce the Income Before Tax of banking companies by 22.729persen. The regression coefficient variable of the Third Party Fund (DPK) of 1.031 (positive coefficient) states that in every increase of public fund of one million rupiahs, there will be an increase in the company profit (Income Before Tax) as much as 1.031 million rupiahs.

\section{Discussion}

\section{The Effect of Non-Performing Financing on the Profit (Income Before tax)}

Based on the results of statistical tests in Table 4.8, NPF variable has a significance value of 0.01 which is smaller than 0.05 . Meanwhile, the results $t$ count shows that $t$ count is $2.697>t$ table 2.01954 and its direction is negative. Therefore, the alternative hypothesis (H1) is accepted, means that the NPF variable has a negative and significant effect on the Profit (IBT) with a significance level of 0.010. This means that if there is a decrease in the NPF value of a banking company with the assumption that other variables are constant, it will be followed by an increase in Profit. Non Performing Financing is a comparison between problematic financing and financing disbursed by the bank. Collectability is the classification of the borrower's ability to return the loan provided by the bank (SigitSetiawan, 2011). The rate of return on financing provided by the depositor to the bank in other words that NPF is the bad financing level in the bank. NPF is known for calculating Non-Current Financing to Total Financing (Tri JokoPurwanto, 2011). The results of this study are in accordance with the research conducted by (SigitSetiawan, 2011), and (Tri JokoPurwanto, 2011) who found that NPF negatively and significantly affected the Profit.

\section{The Effect of the Third Party Fund in the Profit (Income Before Tax)}

DPK variable has a significance value of 0.000 which is smaller than 0.05 . Meanwhile, the result of $t$ count shows that $\mathrm{t}$ calculate $7,395>\mathrm{t}$ table 2.01954 , then alternative hypothesis $(\mathrm{H} 2)$ is accepted which means that DPK variable 
has a positive and significant effect on Profit (IBT) with the significance level of 0.000 . This means that if there is an increase in third-party funds of banking companies assuming that other variables are constant, it will be followed by an increase in profit (IBT). The rotation of Third Party Funds which shows the fluctuation of sharia banking in DPK collection can affect the size of the financing distribution, as stated by Antonio Syafi'i (2010): "The amount of funds collected by a bank is a measure in assessing the level of public trust in the bank. One fund source that can be used by banks for financing is deposit "(WindiWidia, 2012). Funds or financing in Sharia banks may be in the form of giro deposits, savings deposits, and time deposits. However, the financial statements of sharia banks are better known as Third Party Funds (Fatimatuzzahro, 2015). The results of this study are in accordance with research conducted by (WindiWidia, 2012), and (Fatimatuzzahro, 2015) which found that DPK has a significant and positive effect on Profit.

\section{The Effect of Financing Ration on Profit (Income Before Tax)}

$\mathrm{RF}$ variable has a significance value of 0.631 which is greater than 0.05 . Meanwhile, the result of $t$ count shows that $\mathrm{t}$ count $0.484<\mathrm{t}$ table 2.01954 , therefore, the alternative hypothesis (H3) is rejected and receives $\mathrm{H} 0$ which means that the RF variable has no significant effect on Profit (IBT). This happens because financing sharing results have a high risk or cost incurred in the management of profit-sharing financing is higher than other types. Revenuesharing which is derived from the distribution of profit-sharing financing may still not be optimally obtained, therefore it is not able to offset the costs issued yet. Therefore, the revenue-sharing obtained from the revenuesharing division is still not able to optimize the ability of Sharia Commercial Bank in generating the profit. Thus, in the end, it will affect the decrease in profit of Sharia Public Bank. The results of this study are in line with the results of the previous research conducted by KARIMAH, 2015 entitled "The Effect of Profit Sharing Financing and Sale Financing of Sharia Banks In Indonesia "and Farida Purwaningsih, 2015 entitled "The Effect of Mudharabah Savings, Mudharabah-Musyarakah Financing And Other Operating Income on Profit - Study at Sharia Jatim Bank Period 2007-2015 ". The results of the two studies show that the revenue-sharing financing has no effect on profit.

\section{The Effect of Inflation on Profit (Income Before Tax)}

INF variable has a significance value of 0.328 which is smaller than 0.05 , and the result of $t$ count shows that $t$ count $0.990>\mathrm{t}$ table 2.01954 , therefore the alternative hypothesis $(\mathrm{H} 4)$ is rejected and $\mathrm{H} 0$ is accepted which means that INF variable has no significant effect o Profit (IBT). This happens because, with the higher inflation, there will be an increase in bank interest rates. This happens as the way the government attracts the public interest to disburse too much money to the bank. Bank Muamalat as a sharia bank, does not use any interesting system in its operation. The result of this research is in line with the previous research conducted by RavikaFauziah, 2011 entitled "The Analysis of Inflation Effect on Profitability Level Of Bank Muamalat Indonesia and Bank Central Asia (BCA) in 2007-2011", and research results conducted by EdhiSatriyoWibowo, 2013 entitled "The Analysis of The Effect of Interest Rates, Inflation, CAR, BOPO, NPF on Sharia Bank Profitability". The results of the two studies show that the profit sharing financing has no effect on profit.

\section{Conclusions}

Based on the results of the research and discussion described in the previous chapter on Non-Performing Finance, Third Party Funds, Financing Ratios, and Inflation on Profit Loss Sharing (Profit) at Sharia Commercial Bank in Indonesia Period 2012 - 2016, thus can be drawn some conclusions as follows:

1. The variable of Non-Performing Finance, Third Party Fund, Financing and Inflation Ratio affect simultaneously on Profit loss Sharing (Profit).

2. The variable of Non-Performing Finance partially has a negative and significant effect on the Profit loss Sharing (Profit).

3. The variable of Third Party Fund (DPK) partially has a positive and significant effect on Profit loss Sharing (Profit).

4. The variable of Financing Ratio and Inflation has no significant effect on Profit loss Sharing (Profit).

\section{Suggestions}

After conducting the research, discussion, and formulate the conclusions, the writer can provide some suggestions based on research results obtained from this study, such as:

1. Banking management should maximize the collection effort to the receivables, because the faster the receivables are collected, the faster the receivables are turned into cash that can be used to finance the operational activities of the company so that the opportunity to obtain profit loss sharing (profit) is higher.

2. In order to increase the financing of Sharia Banking in Indonesia, banking management should require the attention of the third party funds (DPK). In order to collect the third party funds better with a further assessment on the optimization of third-party fund sources, among others, is by increasing the public trust in the performance, capability, integrity, and credibility of sharia banking. Ensure the security of clients' funds, services, and management as well as the expected profit derived from the deposit of funds.

3. In order to increase the profit of Sharia banking in Indonesia, the banking management should require the 
attention of the distribution of financing sourced from the third party fund collection. In order to optimize the management of third-party funds better is by disbursing the financing that is by reviewing the trust and guarantee of the customer funds security, services and further review on the variation of the financing contracts with profit sharing in accordance with the customer needs so as to increase the financing disbursing to parties which lack funds

\section{References}

Adiwarman, Karim. 2009. Islamic Bank. Jakarta: PT. Raja Grafindo Persada.

Al - Qur'an Al - Karim. Annisa / 4: 12.

Al - Qur'an Al - Karim. Shad / 38: 24.

Anthony, R.N. and V.Govindarajan. 1995. Management Control System. International Student Edition Eight Edition. Richard D. Irwin Inc. U.S.A

Anton Hermanto Gunawan. 1991. Government Budget and Inflation. Jakarta: Gramedia

Antonio Syafi'i. 2002. Islamics Bank: A General Introduction, Tazkia Institute, Jakarta.

Antonio Syafi'i. 2004. Islamics Bank: from Theory to Practice, Gema Insani, Jakarta

Antonio, Syafi'i, Islamics Bank: from Theory to Practice, Jakarta: Gema Insani Press, 2001

Bank Indonesia (2005-2011). Sharia Commercial Bank Published Financial Report (http://www.bi.go.id)

Bank Indonesia: Circular Letter: Number 15/26 / DPbS dated 10 July 2013 Concerning Implementation of Indonesian Islamic Banking Accounting Guidelines.

Bank Indonesia Circular Letter: Number 7/56 / DPbS dated 9 December 2005 concerning the Annual Report, Quarterly and Monthly Published Financial Reports and certain Reports from the Bank Submitted to Bank Indonesia.

Bank Indonesia Regulation: No. 4/1 / PBI / 2002 Concerning Changes in Business Activities of Conventional Commercial Banks to Commercial Banks Based on Sharia Principles and Opening of Bank Offices Based on Sharia Principles by Commercial Banks.

Bank Indonesia: Islamic Banking Statistics, 2005-2011. (http://www.bi.go.id)

Darmadi, Salim. 2013. Corporate Governance Disclosure in The Annual Report: An Exploratory Study on Indonesian Islamic Banks. Humanomics. Volume 29 (1); 4-23.

Dwi Oktavia, Linda. 2009. Effect of Sbi Interest Rate, Rupiah Exchange Rate, and Inflation on Corporate Financial Performance Before and After Privatization. Journal. Depok: Gunadarma University Research Institute.

Garin Pratiwi Solihati (2018) Sinergy of Working Capital and Intellectual Capital to the Creation of Profit as the Source of Local Revenue (An Emphirical Study at BPR in West Java in 2012-2016), Research Journal of Finance and Accounting, Vol 9, No 14, pp. 42-55

Ghozali, Imam. 2011. Application of Multivariate Analysis with IBM SPSS 19. Edition 5. Semarang: Diponegoro University.

Harahap, Sofyan Safri, Wiroso, and Yusuf, Muhammad. 2006. Accounting for Islamic Banking. Revised Edition. Jakarta: LPFE-Usakti.

Harahap, Sofyan Syafri. 2001. Towards Formulation of Islamic Accounting Theory. Jakarta: Quantum Library.

Jensen \& Meckling, 1976, The Theory of Firm: Managerial Behavior, Agency Cost, and Ownership Structure, Journal of Financial and Economics, 3: 305-360.

Khan, Tariqulla and Ahmad (2001). Risk Management on Analysis of Issues in Islamic Financial Industry. Islamic Research and Training Institute: Islamic Deputy Bank

Messier et.al. 2008. Auditing and Assurance Services. Translation by Nuri Hinduan, Jakarta: Salemba Empat

Mohammed. 2005. Islamic Bank Financing Management, UPP AMK YKPN, Yogyakarta.

Muhammad, 2001, Technique of Calculating Profit Sharing in Islamic Banks. Yogyakarta, UII Press

Mustafa edwin nasution, ranti wiliasih, 2007. Profit sharing and moral hazard in the distribution of third party funds for sharia commercial banks in Indonesia. University of Indonesia.

Nengzih (2015) The Adoption of IFRS - Impact on Profitability Rate and Tax Income: Evidence from Companies Indonesia Listed in Indonesian Stock Exhange, Research Journal of Finance and Accounting, Vol 6, No 11, pp. $174-181$

Nur, Moh. Iskandar.2014. Influence of Financial Performance on Mudharabah Deposits and Equity Return Rate at Islamic Commercial Banks in Indonesia. UNDIP, Thesis. Semarang.

Parmudi, Mochammad. 2005. History \& Doctrine of Islamic Banks. Yogyakarta: Pole.

Pramono, heroine. (2013). Optimizing profit-sharing financing in Islamic Banks in Indonesia.

Pratami, Wuri Arianti Novi and Muharam, Harjum, 2012. Analysis of the effect of third party funds (DPK), capital adequacy ratio (car), non-performing financing (NPF) and return on assets (RAO) on financing in Islamic banking (case study on bank muamalat indonesia period 2001-2011). Undergraduate thesis, diponegoro university

Purwanto, tri joko, 2011. Analysis of the magnitude of the influence of financing, financing to deposit ratio (fdr) 
and the ratio of non-performing financing (npf) to the profits of Islamic Banks. Thesis. IPB, Bogor.

Puspasari, Rosana 2014. Effects of Social Performance on Profitability of Islamic Banks. Airlangga University, Indonesia Thesis.

Rahardja, Prathama and Mandala Manurung.2004. Introduction to Macroeconomic Theory. Faculty of Economics, University of Indonesia. Jakarta.

Rahman, Aulia Fuad and Ridha Rochmanika, 2012. Effects of Purchase Financing, Profit Sharing Financing, and Non Performing Financing Ratio on Profitability of Sharia Commercial Banks in Indonesia. Articles of the Faculty of Economics and Business Universitas Brawijaya

Raja Adri Satriawan Surya. 2012. IFRS + Financial Accounting Version. Graha Ilmu, Yogyakarta.

Republic of Indonesia Number 21 of 2008 concerning Islamic Banking.

Rokhmad Subagiyo, Muhammad Nizar \& Raden Haryo. (2012). Islamic Banking Accounting Accounting for Fundraising. Malang: Kurnia Advertising.

Soemarso. 2005. An Introduction to Accounting. Revised Edition, Jakarta: Salemba Empat.

Sri Nurhayati, Wasilah, Islamic Accounting in Indonesia. (Jakarta: Salemba Empat, 2009), h. 13

Suwiknyo, Dwi. 2010. Analysis of Islamic Banking Financial Statements. Yogyakarta: Student Library

Tarsidin, 2010, Sharing Results: Concepts and Analysis. (Jakarta, FEUI Publishing Agency)

Wahyu Kinasih, Septrivia. (2013). Effect of Risk Profile Types of Financing on Non-Performing Financing Ratios of Islamic Banks in Indonesia, Thesis. Jakarta: University of Indonesia

Weygandt, Jerry J and Kieso, Donald E and Kimmel, Paul D (2007) Accounting Principle Introduction to Accounting, Seventh Edition, Salemba Empat Publisher, Jakarta,

Wiliasih, Retno. 2005. Profit Sharing and Moral Hazard in Third Party Funds Distribution of Islamic Commercial Banks in Indonesia. Thesis. University of Indonesia. Jakarta

Yaya, Rizal., Martawireja, Aji Erlangga., And Abdurahim, Ahim. 2009. Islamic Banking Accounting Theory and Contemporary Practice Based on Papsi 2013 Edition 2. Jakarta: Salemba Empat 